\title{
Changes in health indicator gaps between First Nations and other residents of Manitoba
}

\author{
Alan Katz MBChB MSc, Marcelo L. Urquia PhD, Leona Star MDP, Josée G. Lavoie PhD, Carole Taylor MSc, \\ Dan Chateau PhD, Jennifer E. Enns PhD, Myra J. Tait JD LLM, Charles Burchill MSc
}

Cite as: CMAJ 2021 December 6;193:E1830-5. doi: 10.1503/cmaj.210201

\begin{abstract}
Background: The Truth and Reconciliation Commission of Canada has called for better reporting of health disparities between First Nations people and other Canadians to close gaps in health outcomes. We sought to evaluate changes in these disparities using indicators of health and health care use over the last 2 decades.
\end{abstract}

Methods: We used linked, wholepopulation, administrative claims data from the Manitoba Centre for Health Policy for fiscal years $1994 / 95$ to $1998 / 99$ and $2012 / 13$ to $2016 / 17$. We measured indicators of health and health care use among registered First
Nations and all other Manitobans, and compared differences between these groups over the 2 time periods.

Results: Over time, the relative gap between First Nations and all other Manitobans widened by $51 \%$ (95\% confidence interval $[\mathrm{Cl}] 42 \%$ to $60 \%$ ) for premature mortality rate. For potential years of life lost, the gap widened by $54 \%$ (95\% $\mathrm{Cl} 51 \%$ to $57 \%$ ) among women and by $32 \%(95 \% \mathrm{Cl} 30 \%$ to $35 \%)$ among men. The absolute gap in life expectancy widened by 3.14 years $(95 \% \mathrm{Cl} 2.92$ to 3.36) among men and 3.61 years $(95 \% \mathrm{Cl}$ 3.38 to 3.84 ) among women. Relative gaps widened by $20 \%$ (95\% Cl $12 \%$ to
$27 \%$ ) for ambulatory specialist visits, by $14 \%$ (95\% Cl $12 \%$ to $16 \%$ ) for hospital separations and by $50 \%(95 \% \mathrm{Cl} 39 \%$ to $62 \%)$ for days spent in hospital, but narrowed by $33 \%(95 \% \mathrm{Cl}-36 \%$ to $-30 \%)$ for ambulatory primary care visits, by $22 \%$ (95\% Cl $-27 \%$ to $-16 \%$ ) for mammography and by $27 \%(95 \% \mathrm{Cl}-40 \%$ to $-23 \%$ ) for injury hospitalizations.

Interpretation: Disparities between First Nations and all other Manitobans in many key indicators of health and health care use have grown larger over time. New approaches are needed to address these disparities and promote better health with and for First Nations. omprehensive data on the health of First Nations people in Canada are urgently needed. ${ }^{1,2}$ This is a priority identified by the Truth and Reconciliation Commission of Canada, which highlights the striking health disparities between Indigenous and non-Indigenous populations in Canada and recognizes the disparities in their Calls to Action as "a direct result of previous Canadian government policies." 3 These health disparities are understood to be part of the continuing impact of colonization and genocidal policies aimed specifically at Indigenous people. ${ }^{4,5}$

The underlying causes of the health gap between Indigenous and non-Indigenous people, resulting from attempts by European settlers to assimilate Indigenous people into their own societies, have been detailed elsewhere. ${ }^{6}$ The collective trauma that Indigenous populations have experienced through colonial policies and practices include, among others, racism and marginalization in virtually every aspect of their lives; major disruptions of families and communities through forced attendance at residential schools and by the child welfare system; trauma from physical, emotional and sexual abuse, carried over into future generations; and damage to their Indigenous identity through loss of culture, language, traditions and teachings. ${ }^{6,7}$ Other social determinants (e.g., poverty, social exclusion and poor access to clean water, quality housing, education and heath services) and the governments' failure to address these issues also influence the health of First Nations people..$^{8,9}$

A previous population-based study of First Nations' health and health care use in Canada, published in 2002, focused on the Manitoba population, which has the highest proportion of First Nations residents among Canadian provinces..$^{10}$ It identified substantial gaps in the health of First Nations and their access to health services compared with other Manitobans. Others have since reported on health disparities between Indigenous peoples and other Canadians; ${ }^{11-14}$ however, the Manitoba data provide a unique opportunity to compare changes in health-related outcomes over nearly 2 decades. In the present study, we sought to compare indicators of health and health care use between First Nations people and other residents of Manitoba, to determine whether the gap between the 2 groups has changed over the past 18 years and establish whether any progress has been made in improving First Nations' health. 


\section{Methods}

\section{Data sources}

We used routinely collected administrative claims data held in the Manitoba Population Research Data Repository at the Manitoba Centre for Health Policy, which contains deidentified, person-level data for virtually the entire population of Manitoba that, for some data sets, spans more than 30 years. The data contain no names and addresses, but are linkable by way of a scrambled numeric identifier that is attached to each record before the data are added to the Repository. Researchers at the Manitoba Centre for Health Policy partnered with the First Nations Health and Social Secretariat of Manitoba to access a deidentified research file from the First Nations and Inuit Health Branch that comprises data from First Nations individuals in Manitoba who are registered under the Indian $A c t^{15}$ as "status Indians." Previous work has validated the Repository data and shown excellent linkage accuracy. ${ }^{16-18}$

\section{Study population}

The study population included nearly all residents of Manitoba registered for provincial health insurance in 2016. We excluded wards of the Public Guardian and Trustee since they could not be assigned postal codes, meaning that we could not estimate their socioeconomic status or residence data. Wards include adults who are mentally incompetent or vulnerable adults who are not mentally capable of making decisions independently, people who have granted a power of attorney to the Public Trustee, people who have died in Manitoba with no one else capable or willing to act as administrator or executor, and people who are younger than 18 years of age or under a legal disability.

We included all Manitobans identified as registered First Nations as part of 1 study group, regardless of whether or not they lived in a First Nations community ("on-reserve"). There are 63 distinct First Nations and 5 Indigenous linguistic groups in Manitoba. The other study group comprised all other Manitobans, including non-Indigenous residents of Manitoba, as well as Inuit, Métis and other individuals who were ineligible or had not applied to be registered as First Nations. The decision to include Métis and Inuit as part of all other Manitobans was made out of respect to our First Nations partners, who are adamant that comparisons be made in accordance with the guiding principles of First Nations data sovereignty ${ }^{19}$ and the distinctionsbased research approach supported by the Government of Canada. ${ }^{20}$

\section{Measurements}

We chose the indicators in this study to match those previously reported for the study population ${ }^{10}$ and in response to the Truth and Reconciliation Commission's Call to Action \#19 to assess long-term trends in health outcomes, like life expectancy and availability of health services. We also chose indicators to address specific questions raised by our First Nations coinvestigators. The health outcomes we measured were premature mortality rate, potential years of life lost and life expectancy. We measured indicators of health care use, including ambulatory visits to primary care and specialist care physicians, hospital separations, days in hospital, hospitalization for injury and mammography. Appendix 1 (available at www.cmaj.ca/lookup/ doi/10.1503/cmaj.210201/tab-related-content) lists the indicator definitions and the data sets from which they originated.

\section{Analyses}

We reported age- and sex-standardized health and health care use indicators for registered First Nations and all other Manitobans, and compared them during 2 time periods (period 1: fiscal years 1994/95-1998/99, period 2: fiscal years 2012/13-2016/17). Data from period 2 were the most recent data available at the time of the study; data from period 1 were from the 2002 study of First Nations' health and health care use. ${ }^{10}$ Comparisons within each period were based on aggregate data using additive and multiplicative approaches, expressed as differences and ratios with $95 \%$ confidence intervals (Cls), as applicable. We estimated changes in the gaps between First Nations and all other Manitobans over time with difference-in-differences analyses to obtain absolute rate differences and relative rate ratios, with $95 \% \mathrm{Cls}$. A difference-in-differences analysis is a quasiexperimental design that is used in observational settings to compare changes in outcomes over time between 2 populations, accounting for secular trends. ${ }^{21}$ We modelled difference-in-differences by including an interaction term between groups and time periods that generated estimates for the change in the gap between First Nations and all other Manitobans from period 1 to period 2 . We used an identity link to model absolute differences in the gap (gap between First Nations and all other Manitobans in period 2 minus gap in period 1), expressed as absolute differences, and a log link to model relative differences in the gap (gap between First Nations and all other Manitobans in period 2 divided by gap in period 1), expressed as relative differences (i.e., relative rate ratios). We conducted all analyses using SAS Version 9.4.

\section{Ethics approval}

The study was approved by the University of Manitoba Human Research Ethics Board (HS2016:201), the Health Information Research Governance Committee of the First Nations Health and Social Secretariat and the Health Information Privacy Committee of the Manitoba government (No. 2016/2017-07).

\section{Results}

The study population included nearly every person (> 99\%) living in Manitoba in 2016 (Figure 1), comprising 140910 registered First Nations individuals and 1204641 other Manitobans.

Indicators of health and the gaps between First Nations and all other Manitobans are shown in Table 1. From period 1 to period 2, the premature mortality rate decreased for both First Nations and all other Manitobans, and the absolute gap between them decreased slightly. However, because the relative decline over time was less pronounced among First Nations, the relative gap in the premature mortality rate between First Nations people and all other Manitobans increased by $51 \%$ over time. Potential years of life lost were higher among First Nations than all other 


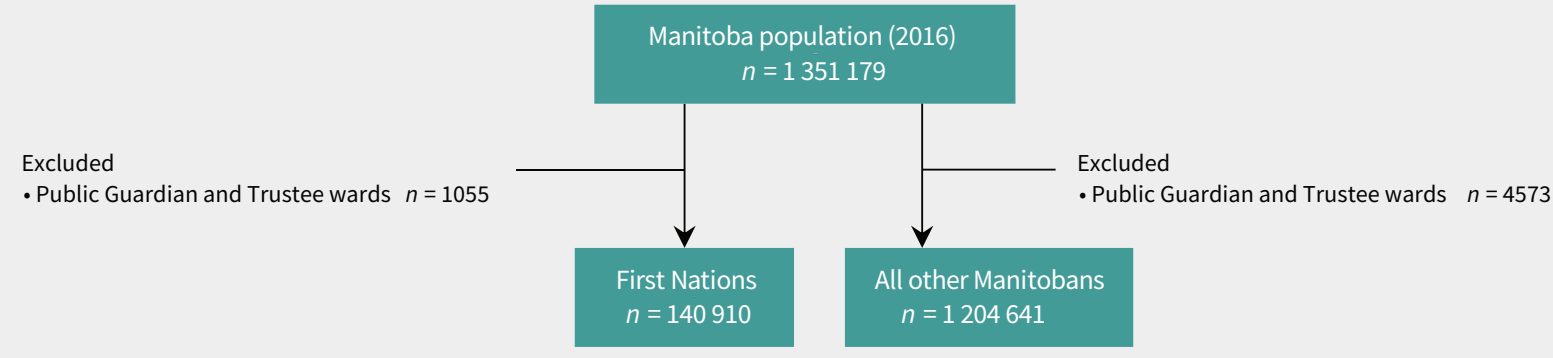

Figure 1: Study population flow chart.

Table 1: Changes in health indicators between registered First Nations people and all other residents of Manitoba between 1994/95-1998/99 and 2012/13-2016/17

Time period 1: 1994/95-1998/99

Time period 2: 2012/13-2016/17

\begin{tabular}{|c|c|c|c|c|c|c|c|c|c|c|}
\hline Variable† & $\begin{array}{c}\text { First } \\
\text { Nations }\end{array}$ & Other & $\begin{array}{c}\text { Difference } \\
(95 \% \mathrm{CI})\end{array}$ & $\begin{array}{c}\text { Ratioł } \\
(95 \% \mathrm{CI})\end{array}$ & $\begin{array}{c}\text { First } \\
\text { Nations }\end{array}$ & Other & $\begin{array}{c}\text { Difference } \\
(95 \% \mathrm{CI})\end{array}$ & $\begin{array}{l}\text { Ratioł } \\
(95 \% \mathrm{CI})\end{array}$ & $\begin{array}{c}\text { Difference§ } \\
(95 \% \mathrm{CI})\end{array}$ & $\begin{array}{c}\text { Change§, \% } \\
(95 \% \mathrm{CI})\end{array}$ \\
\hline $\begin{array}{l}\text { Premature } \\
\text { mortality rate, } \\
\text { per } 1000 \text { people }\end{array}$ & 6.61 & 3.30 & $\begin{array}{c}3.31 \\
(3.11 \text { to } \\
3.51)\end{array}$ & $\begin{array}{c}2.00 \\
(1.94 \text { to } \\
2.07)\end{array}$ & 4.35 & 1.44 & $\begin{array}{c}2.91 \\
(2.71 \text { to } \\
3.11)\end{array}$ & $\begin{array}{c}3.02 \\
(2.87 \text { to } \\
3.18)\end{array}$ & $\begin{array}{c}-0.40 \\
(-0.12 \text { to } \\
-0.69)\end{array}$ & $\begin{array}{c}51 \\
\text { (42 to } 60)\end{array}$ \\
\hline \multicolumn{11}{|c|}{ Potential years of life lost, per 1000 people } \\
\hline Women & 103.26 & 36.47 & $\begin{array}{c}66.79 \\
(65.44 \text { to } \\
68.13)\end{array}$ & $\begin{array}{c}2.83 \\
(2.79 \text { to } \\
2.87)\end{array}$ & 109.09 & 24.97 & $\begin{array}{c}84.12 \\
(83.04 \text { to } \\
85.19)\end{array}$ & $\begin{array}{c}4.37 \\
(4.31 \text { to } \\
4.43)\end{array}$ & $\begin{array}{c}17.33 \\
(15.61 \text { to } \\
19.05)\end{array}$ & $\begin{array}{c}54 \\
\text { (51 to } 57)\end{array}$ \\
\hline Men & 158.29 & 62.53 & $\begin{array}{c}95.76 \\
(94.14 \text { to } \\
97.38)\end{array}$ & $\begin{array}{c}2.53 \\
(2.50 \text { to } \\
2.56)\end{array}$ & 137.00 & 40.85 & $\begin{array}{c}96.15 \\
(94.94 \text { to } \\
97.35)\end{array}$ & $\begin{array}{c}3.35 \\
(3.32 \text { to } \\
3.39)\end{array}$ & $\begin{array}{c}0.39 \\
(-2.41 \text { to } \\
1.63)\end{array}$ & $\begin{array}{c}32 \\
\text { (30 to } 35)\end{array}$ \\
\hline \multicolumn{11}{|c|}{ Life expectancy at birth, yr } \\
\hline Women & 73.18 & 81.40 & $\begin{array}{c}-8.22 \\
(-8.07 \text { to } \\
-8.37)\end{array}$ & $\begin{array}{c}0.90 \\
(0.90 \text { to } \\
0.90)\end{array}$ & 72.42 & 83.78 & $\begin{array}{c}-11.36 \\
(-11.21 \text { to } \\
-11.51)\end{array}$ & $\begin{array}{c}0.86 \\
(0.86 \text { to } \\
0.87)\end{array}$ & $\begin{array}{c}3.14 \\
(2.92 \text { to } \\
3.36)\end{array}$ & $\begin{array}{c}4 \\
\text { (3 to } 4)\end{array}$ \\
\hline Men & 68.35 & 76.07 & $\begin{array}{l}-7.75 \\
(-7.59 \text { to } \\
-7.91)\end{array}$ & $\begin{array}{c}0.90 \\
(0.89 \text { to } \\
0.90)\end{array}$ & 68.06 & 79.42 & $\begin{array}{c}-11.36 \\
(-11.20 \text { to } \\
-11.52)\end{array}$ & $\begin{array}{c}0.86 \\
(0.85 \text { to } \\
0.86)\end{array}$ & $\begin{array}{c}3.61 \\
(3.38 \text { to } \\
3.84)\end{array}$ & $\begin{array}{c}5 \\
\text { (4 to } 5)\end{array}$ \\
\hline
\end{tabular}

Note: $\mathrm{Cl}=$ confidence interval.

*We estimated the changes in the size of the gaps between the First Nations and all other people in Manitoba between period 2 and period 1 with difference-in-differences analyses to obtain absolute rate differences and relative rate ratios with $95 \%$ confidence intervals. We expressed the relative rate ratios as the percent change in the relative gap between the First Nations and other people in Manitoba. Positive values indicate a widening of the gap between the 2 periods, and negative values a narrowing of the gap.

†Premature mortality rate (adjusted for age and sex) is the rate of death before the age of 75 years. Potential years of life lost (adjusted for age) is the number of years lost when a person dies before the age of 75 . Life expectancy (adjusted for age) is the expected length of life (in years) from birth to death.

†First Nations v. all other Manitobans.

$\S$ Difference is the difference in rate differences between period 2 and period 1 . Change is the relative change in the rate ratio between period 2 and period 1.

Manitobans in period 1; over time, they increased slightly among First Nations women, but decreased among all other Manitobans, contributing to a widening gap of $17.33(95 \% \mathrm{Cl} 15.61$ to 19.05) additional years lost per 1000 people (a 54\% increase). Among men, potential years of life lost decreased over time for both First Nations and all other Manitobans and the absolute difference remained constant, but the persistence of much higher values among First Nations men meant that the relative gap increased by $32 \%$ (95\% Cl $30 \%$ to $35 \%$ ). Life expectancy at birth for both sexes declined among First Nations people from 1994/95-1998/99 to 2012/13-2016/17, but increased among all other Manitobans. As a result, the absolute gap in life expectancy between First Nations and all other Manitobans increased from about 8 years to about 11 years over time, representing a relative increase in the gap of $4 \%$ to $5 \%$.

Indicators of health care use, and the gaps between First Nations and all other Manitobans are shown in Table 2. Rates of primary care visits were higher among First Nations than all other Manitobans in period 1, but this gap was no longer evident in period 2, mainly because of a reduction in the number of visits among First Nations. First Nations people had lower rates of specialist visits than all other Manitobans in both periods, but the absolute gap decreased from 0.38 to 0.14 fewer visits per person. First Nations had more than twice the rate of hospital separations than all other Manitobans in both periods. Although these rates declined over time for both groups, the 
Table 2: Changes in health care use between registered First Nations people and all other residents of Manitoba between $1994 / 95-1998 / 99$ and 2012/13-2016/17

\begin{tabular}{|c|c|c|c|c|c|c|c|c|c|c|}
\hline \multirow[b]{2}{*}{ Variable } & \multicolumn{4}{|c|}{ Time period 1: 1994/95-1998/99 } & \multicolumn{4}{|c|}{ Time period 2: 2012/13-2016/17 } & \multicolumn{2}{|c|}{ Change in gap over time* } \\
\hline & $\begin{array}{c}\text { First } \\
\text { Nations }\end{array}$ & Other & $\begin{array}{l}\text { Difference } \neq \\
(95 \% \mathrm{CI})\end{array}$ & $\begin{array}{c}\text { Ratioł } \\
(95 \% \mathrm{Cl})\end{array}$ & $\begin{array}{c}\text { First } \\
\text { Nations }\end{array}$ & Other & $\begin{array}{c}\text { Difference } \neq \\
(95 \% \mathrm{CI})\end{array}$ & $\begin{array}{c}\text { Ratioł } \\
(95 \% \mathrm{Cl})\end{array}$ & $\begin{array}{c}\text { Difference§ } \\
(95 \% \mathrm{CI})\end{array}$ & $\begin{array}{c}\text { Change§, \% } \\
(95 \% \mathrm{CI})\end{array}$ \\
\hline $\begin{array}{l}\text { Ambulatory } \\
\text { primary care } \\
\text { visits, per person }\end{array}$ & 5.23 & 3.57 & $\begin{array}{c}1.66 \\
(1.51 \text { to } \\
1.81)\end{array}$ & $\begin{array}{c}1.46 \\
(1.42 \text { to } \\
1.51)\end{array}$ & 3.19 & 3.25 & $\begin{array}{c}-0.06 \\
(-0.16 \text { to } \\
0.04)\end{array}$ & $\begin{array}{c}0.98 \\
(0.95 \text { to } \\
1.01)\end{array}$ & $\begin{array}{c}-1.72 \\
(-1.54 \text { to } \\
-1.90)\end{array}$ & $\begin{array}{c}-33 \\
(-36 \text { to }-30)\end{array}$ \\
\hline $\begin{array}{l}\text { Hospital } \\
\text { separations, per } \\
1000 \text { people }\end{array}$ & 348.07 & 156.20 & $\begin{array}{c}191.86 \\
(188.60 \text { to } \\
195.12)\end{array}$ & $\begin{array}{c}2.23 \\
(2.20 \text { to } \\
2.26)\end{array}$ & 153.43 & 60.42 & $\begin{array}{c}93.01 \\
(91.08 \text { to } \\
94.93)\end{array}$ & $\begin{array}{c}2.54 \\
(2.36 \text { to } \\
2.50)\end{array}$ & $\begin{array}{c}-98.86 \\
(-102.64 \text { to } \\
-95.07)\end{array}$ & $\begin{array}{c}14 \\
\text { (12 to } 16)\end{array}$ \\
\hline $\begin{array}{l}\text { Hospital days, } \\
\text { per person }\end{array}$ & 1.75 & 1.05 & $\begin{array}{c}0.70 \\
(0.61 \text { to } \\
0.79)\end{array}$ & $\begin{array}{c}1.67 \\
(1.58 \text { to } \\
1.76)\end{array}$ & 1.05 & 0.42 & $\begin{array}{c}0.63 \\
(0.58 \text { to } \\
0.68)\end{array}$ & $\begin{array}{l}2.50 \\
(2.36 \text { to } \\
2.65)\end{array}$ & $\begin{array}{c}-0.07 \\
(-0.18 \text { to } \\
0.03)\end{array}$ & $\begin{array}{c}50 \\
\text { (39 to } 62 \text { ) }\end{array}$ \\
\hline $\begin{array}{l}\text { Mammography, } \\
\text { per } 100 \text { women }\end{array}$ & 25.83 & 55.91 & $\begin{array}{c}-30.11 \\
(-31.58 \text { to } \\
-28.64)\end{array}$ & $\begin{array}{c}0.46 \\
(0.44 \text { to } \\
0.50)\end{array}$ & 35.36 & 58.57 & $\begin{array}{c}-24.01 \\
(-24.97 \text { to } \\
-23.05)\end{array}$ & $\begin{array}{c}0.59 \\
(0.57 \text { to } \\
0.61)\end{array}$ & $\begin{array}{c}-5.99 \\
(-7.80 \text { to } \\
-4.24)\end{array}$ & $\begin{array}{c}-22 \\
(-27 \text { to }-16)\end{array}$ \\
\hline
\end{tabular}

Note: $\mathrm{Cl}=$ confidence interval.

*We estimated the changes in the size of the gaps between the First Nations and all other people in Manitoba between period 2 and period 1 with difference-in-differences analyses to obtain absolute rate differences and relative rate ratios with $95 \%$ confidence intervals. We expressed the relative rate ratios as the percent change in the relative gap between the First Nations and other people in Manitoba. Positive values indicate a widening of the gap between the 2 periods, and negative values a narrowing of the gap.

†All variables are adjusted for age and sex. Ambulatory specialist visits: the visits per person-year to a specialist physician while not admitted to a hospital or nursing home. Specialist physicians include all internal medicine specialists, pediatricians, psychiatrists, obstetricians and gynecologists, and surgeons. Hospital separations: the rate of hospital admissions, including transfers between hospitals, out-of-province hospitalizations and people who were hospitalized while giving birth. Hospital days: average number of days spent in hospital per person per year. Injury hospitalizations: Hospitalizations per year with a diagnosis code for external cause of injury in the hospital discharge abstract. Mammography: rate among women eligible for screening (age 50-74 yr) who had a mammogram in a 2-year period.

łFirst Nations v. all other Manitobans.

$\S$ Difference is the difference in the rate difference between period 2 and period 1 . Change is the relative change in the rate ratio between period 2 and period 1.

absolute decline was greater among First Nations people, resulting in a decreased absolute gap compared with all other Manitobans, by 98.86 hospital separations per 1000 people. However, because hospital separations remained much higher among First Nations, the relative gap increased by $14 \%(95 \% \mathrm{Cl}$ $12 \%$ to $16 \%$ ). Similarly, the absolute gap in days spent in hospital was unchanged, but the relative gap increased by 50\% (95\% $\mathrm{Cl} 39 \%$ to $62 \%$ ); although the number of days in hospital decreased over time in both groups, it remained much greater among First Nations than all other Manitobans in both periods. Rates of hospital admissions for injuries were higher among First Nations than all other Manitobans in both time periods and increased in both groups over time, leading to an increase in the absolute gap of 21.25 hospital admissions per 1000 individuals ( $95 \% \mathrm{Cl} 19.47$ to 23.03$)$, but a decrease in the relative gap of $27 \%(95 \% \mathrm{Cl}-40 \%$ to $-23 \%)$. Finally, First Nations people had about half the number of mammograms than all other Manitobans in period 1, with a slight increase in both groups over time. This increase was larger among First Nations and, as a result, the absolute gap narrowed marginally by $5.99(95 \% \mathrm{Cl}$ -4.24 to $-7.8 \%)$, though the relative gap narrowed by $22 \%$ (95\% $\mathrm{Cl}-27 \%$ to $-16 \%)$.

\section{Interpretation}

We present evidence of a widening health gap between First Nations and other people in Manitoba over the last 2 decades, building on previous findings that had already shown substantial disparities in health. ${ }^{10}$ We show that the gaps in premature mortality rate, potential years of life lost and life expectancy at birth have widened from 1994/95-1998/99 to 2012/13-2016/17. We also show gaps in health care use indicators, with important implications for population health and health system resource stewardship. First Nations people had a greater decrease in primary care visits than all other Manitobans over time, despite continuing to have much higher rates of hospitalizations and more days in hospital than other Manitobans. Therefore, the disappearance of the gap in primary care use likely does not reflect improvement over time in health equity, but rather suggests that First Nations people face increasing barriers to accessing ambulatory care despite ongoing, demonstrably higher health care needs. We know from previous research ${ }^{22}$ that the rate of ambulatory care-sensitive hospital admissions among First Nations was 3 times higher than all other Manitobans during period 2. This may explain, at least 
in part, why the relative gap in rates of hospitalization between First Nations and all other Manitobans has widened over time.

Our study used comprehensive population data on nearly all health system contacts by Manitobans and the longitudinal design allowed us to evaluate changes in health over almost 2 decades. The study also exemplifies a robust partnership between the Manitoba Centre for Health Policy and the First Nations Health and Social Secretariat, serving as an example for how research that respects First Nations and their health needs should be conducted.

Similar gaps in key health indicators have been shown in cross-sectional analyses by the National Collaborating Centre for Indigenous Health and Statistics Canada. ${ }^{23-25}$ Underlying causes of these disparities have repeatedly been attributed to a lack of recognition of the effects of colonialism and racism and their contribution to the Indigenous social determinants of health. ${ }^{7,9,26,27}$ The federal government has made efforts to change the trajectory of Indigenous health by investing in mental wellness, ${ }^{28}$ addictions ${ }^{29}$ and essential health care services, ${ }^{30}$ among other efforts. However, our findings suggest that a focus on improving provision of routine health services, rather than addressing the "causes of the causes," 31 has been insufficient to address the health inequities experienced by First Nations. ${ }^{32-34}$ Consequently, although nearly $30 \%$ of federal and provincial health expenditures in Manitoba go to treating First Nations, health disparities have continued to grow..$^{35}$ For these reasons, entities who are tracking progress on the Truth and Reconciliation Commission of Canada's Calls to Action ${ }^{36-38}$ largely give the government a failing grade in their achievements to date.

\section{Limitations}

Our understanding of the health of Indigenous peoples in Canada is limited by the data used to monitor health. There are major challenges in First Nations data coverage and quality, including the need to recognize people who self-identify as First Nations in a respectful, systematic, comprehensive and consistent way. In our study, the Indian Registry, which is defined and controlled by the Indian Act, ${ }^{15}$ determines who is considered a "registered First Nations person"; membership in this group is reported by local band councils. However, amendments to the Indian Act were made during the study years, which had the effect of lifting restrictions for registration, thereby possibly introducing a small amount of variability in the cohort over time that we could not account for. We also recognize that First Nations are diverse and multijurisdictional, and health systems can vary greatly according to geography (remote, rural, onreserve, urban) and provider jurisdiction (federal, provincial or territorial, local or regional, or a combination thereof), which affects the collection of comprehensive and reliable health data. ${ }^{39}$ Health services provided at both federally and provincially managed nursing stations in First Nations communities are not recorded in the provincial data files or the Repository. Since nursing stations are key access points for primary care for First Nations people living on-reserve, the rate of ambulatory primary care visits is likely underestimated for First Nations peo- ple in both time periods. Effectively, this means that First Nations people may have access to more primary care than we report in this study, but given their high rates of hospitalization, it is clear that this care is not meeting their needs as a population. We were limited in our analyses by not having access to individual-level data for 1994/95-1998/99; we had to use aggregate data instead. Finally, administrative and survey data often use universally recognized health indicators, but these measures may not reflect the needs, priorities and conceptions of health of First Nations people.

\section{Conclusion}

For many indicators of health, gaps between First Nations and all other Manitobans have widened over time. These findings indicate that efforts to improve health outcomes among Indigenous people have been insufficient and should provide impetus for renewed action. The Canadian health system must recognize the needs of First Nations, reported here and in many other studies, and take specific actions to decolonize health care, as determined by First Nations. Together, we must continue to work toward equitable health within a culturally respectful and effective health system.

\section{References}

1. Smylie J, Firestone M. Back to the basics: identifying and addressing underlying challenges in achieving high quality and relevant health statistics for Indigenous populations in Canada. Stat J IAOS 2015;31:67-87.

2. Chino M, Ring I, Pulver $L$, et al. Improving health data for Indigenous populations: the international group for Indigenous health measurement. Stat J IAOS 2019;35:15-21.

3. Truth and Reconciliation Commission of Canada: calls to action. Winnipeg: Truth and Reconciliation Commission of Canada; 2015. Available: https:// www2.gov.bc.ca/assets/gov/british-columbians-our-governments/indigenous -people/aboriginal-peoples-documents/calls_to_action_english2.pdf (accessed 2021 Oct. 2).

4. Richmond CAM, Cook C. Creating conditions for Canadian Aboriginal health equity: the promise of healthy public policy. Public Health Rev 2016;37:2.

5. Mitchell T, Arseneau C, Thomas D. Colonial trauma: complex, continuous, collective, cumulative and compounding effects on the health of Indigenous peoples in Canada and beyond. Int J Indig Health 2019;14:74-94.

6. Kirmayer LJ, Gone JP, Moses J. Rethinking historical trauma. Transcult Psychiatry 2014;51:299-319.

7. King M, Smith A, Gracey M. Indigenous Health Part 2: The underlying causes of the health gap. Lancet 2009;374:76-85.

8. Marmot M. Social determinants of health inequalities. Lancet 2005;365:1099-104.

9. Reading J, Halseth R. Pathways to improving well-being for Indigenous peoples: how living conditions decide health. Prince George (BC): National Collaborating Centre for Aboriginal Health; 2013. Available: http://nccah-ccnsa.ca/Publications/Lists/ Publications/Attachments/102/pathways_EN_web.pdf (accessed 2021 May 14).

10. Martens PJ, Bond R, Jebamani L, et al. The health and health care use of registered First Nations people living in Manitoba: a population-based study. Winnipeg: Manitoba Centre for Health Policy; 2002.

11. Lafontaine A. Indigenous health disparities: a challenge and an opportunity. Can J Surg 2018;61:300-1.

12. Key health inequalities in Canada: a national portrait - executive summary. Ottawa: Public Health Agency of Canada; 2018.

13. Phillips-Beck W, Sinclair S, Campbell R, et al. Early-life origins of disparities in chronic diseases among Indigenous youth: pathways to recovering health disparities from intergenerational trauma. J Dev Orig Health Dis 2019;10:115-22.

14. McVicar JA, Poon A, Caron NR, et al. Postoperative outcomes for Indigenous Peoples in Canada: a systematic review. CMAJ 2021;193:E713-22.

15. Indian Act (R.S.C., 1985, c. I-5).

16. Roos LL, Gupta S, Soodeen R-A, et al. Data quality in an information-rich environment: Canada as an example. Can J Aging 2005;24(Suppl 1):153-70.

17. Roos LL, Nicol JP. A research registry: uses, development, and accuracy. J Clin Epidemiol 1999;52:39-47. 
18. Mustard CA, Derksen S, Berthelot JM, et al. Assessing ecologic proxies for household income: a comparison of household and neighbourhood level income measures in the study of population health status. Health Place 1999;5:157-71.

19. Ownership, Control, Access and Possession (OCAP $\left.{ }^{T M}\right)$ : the path to First Nations information governance. Akwesasne (ON): The First Nations Information Governance Centre; 2014. Available: https://achh.ca/wp-content/uploads/2018/07/ OCAP_FNIGC.pdf (accessed 2021 Oct. 24).

20. Principles: respecting the Government of Canada's relationship with Indigenous Peoples. Ottawa: Department of Justice Canada; 2018. Available: https://www. justice.gc.ca/eng/csj-sjc/principles.pdf (accessed 2021 Oct. 24).

21. Warton EM, Parker MM. Oops, I D-I-D it again! Advanced difference-in-differences models in SAS ${ }^{\circledR}$. Paper 25-2018. Sacramento (CA): Western Users of SAS Software; 2018. Available: https://www.lexjansen.com/wuss/2018/25_Final_ Paper_PDF.pdf (accessed 2021 Sept. 18)

22. Katz A, Avery Kinew K, Star L, et al. The health status of and access to healthcare by registered First Nation Peoples in Manitoba. Winnipeg: Manitoba Centre for Health Policy; 2019.

23. The health status of Canada's First Nations, Métis and Inuit Peoples. Toronto: Health Council of Canada; 2005. Available: https://publications.gc.ca/collec tions/collection_2012/ccs-hcc/H174-37-2005-1-eng.pdf (accessed 2021 Oct. 24).

24. Tjepkema M, Bushnik T, Bougie E. Life expectancy of First Nations, Métis and Inuit household populations in Canada. Health Rep 2019;30:3-10.

25. Reading C, Wien F. Health inequalities and the social determinants of Aboriginal Peoples' Health. Prince George (BC): National Collaborating Centre for Aboriginal Health; 2009. Available: https://www.nccih.ca/495/Health_inequalities_ and_the_social_determinants_of_Aboriginal_peoples__health_.nccih?id=46 (accessed 2021 May 14).

26. Reading C. Structural determinants of Aboriginal Peoples' health. In: Greenwood M, de Leeuw S, Lindsay N, et al., editors. Determinants of Indigenous Peoples' Health in Canada: Beyond the Social. Toronto: Canadian Scholars' Press; 2015.

27. Gouldhawke M. The failure of federal Indigenous healthcare policy in Canada. Toronto: Yellowhead Institute, Ryerson University; 2021. Available: https://yel lowheadinstitute.org/2021/02/04/the-failure-of-federal-indigenous-healthcare -policy-in-canada/ (accessed 2021 May 14).

28. Strong leadership: a balanced-budget, low-tax plan for jobs, growth and security. Ottawa: Department of Finance Canada; 2015. Available: https://www. budget.gc.ca/2015/docs/plan/budget2015-eng.pdf (accessed 2021 May 15).
29. Delivering on Truth and Reconciliation Commission calls to action. Gatineau (QC): Crown-Indigenous Relations and Northern Affairs Canada; modified 2019 Sept. 5. Available: https://www.rcaanc-cirnac.gc.ca/eng/1524499024614/1557512659251 (accessed 2021 May 14).

30. Budget 2021: a recovery plan for jobs, growth, and resilience [news release]. Ottawa: Department of Finance Canada; 2021 Apr. 19. https://www.canada.ca/ en/department-finance/news/2021/04/budget-2021-a-recovery-plan-for-jobs -growth-and-resilience.html (accessed 2021 May 15).

31. Marmot M. Inclusion health: addressing the causes of the causes. Lancet 2018;391:186-8.

32. Czyzewski K. Colonialism as a broader social determinant of health. Int Indig Policy J 2011;2. doi: 10.18584/iipj.2011.2.1.5.

33. Greenwood M, de Leeuw S, Lindsay NM, editors. Determinants of Indigenous Peoples' health in Canada: beyond the social. Toronto: Canadian Scholar's; 2018.

34. Loppie S, Reading C, de Leeuw S. Social determinants of health: Indigenous experiences with racism and its impacts. Prince George (BC): National Collaborating Centre for Indigenous Health; 2014. Available: https://www.nccih.ca/docs/ determinants/FS-Racism2-Racism-Impacts-EN.pdf (accessed 2021 May 29).

35. Lavoie JG. A comparative financial analysis of the 2003-04 and 2009-10 health care expenditures for First Nations in Manitoba. Prince George (BC): National Collaborating Centre for Indigenous Health; 2014.

36. Beyond 94: truth and reconciliation in Canada. CBC News 2018; updated 2021 Sept. 27. Available: https://newsinteractives.cbc.ca/longform-single/beyond -94 ? \&cta $=17$ (accessed 2021 May 14).

37. Jewell E, Mosby I. Calls to action accountability: a 2020 status update on reconciliation. Toronto: Yellowhead Institute, Ryerson University; 2020. Available: https:// yellowheadinstitute.org/wp-content/uploads/2020/12/yi-trc-calls-to-action -update-full-report-2020.pdf (accessed 2021 May 15).

38. Progress on realizing the Truth and Reconciliation Commission's calls to action. Ottawa: Assembly of First Nations; 2020. Available: https://www.afn. ca/wp-content/uploads/2020/12/2020_TRC-Report-Card_ENG.pdf (accessed 2021 May 28).

39. Smylie J, Anderson I, Ratima M, et al. Indigenous health performance measurement systems in Canada, Australia, and New Zealand. Lancet 2006;367:2029-31.
Competing interests: Alan Katz serves on the advisory board of the Manitoba Centre for Health Policy in an ex officio capacity. No other competing interests were declared.

This article has been peer reviewed.

Affiliations: Manitoba Centre for Health Policy (Katz, Urquia, Taylor, Chateau, Enns, Burchill) and Family Medicine (Katz), Departments of Community Health Sciences, Rady Faculty of Health Sciences, University of Manitoba; First Nations Health and Social Secretariat of Manitoba (Star); Department of Community Health Sciences (Lavoie), Ongomiizwin Research, Rady Faculty of Health Sciences, University of Manitoba, Winnipeg, Man.; Faculty of Humanities \& Social Sciences, Governance, Law and Management (Tait), Athabasca University, Athabasca, Alta.

Contributors: Alan Katz and Leona Star conceptualized the study. Alan Katz, Marcelo Urquia, Josée Lavoie and Dan Chateau were responsible for study design. Carole Taylor and Charles Burchill managed the data and conducted the analyses. All of the authors assisted with interpretation of results. Jennifer Enns and Myra Tait drafted the manuscript. All of the authors revised it critically for important intellectual content, gave final approval of the version to be published and agreed to be accountable for all aspects of the work.

Content licence: This is an Open Access article distributed in accordance with the terms of the Creative Commons Attribution (CC BY-NC-ND 4.0) licence, which permits use, distribution and reproduction in any medium, provided that the original publication is properly cited, the use is noncommercial (i.e., research or educational use), and no modifications or adaptations are made. See: https://creativecommons.org/licenses/by-nc-nd/4.0/

Funding: Funding for this work was provided as part of a contract between the University of Manitoba and the Manitoba Government Ministry of
Health, Seniors and Active Living (MHSAL). The funders had no input into the study design, implementation, or interpretation of the findings. The conclusions are those of the authors alone, and no official endorsement by the funders was intended or should be inferred.

Data sharing: Data used in this study were derived from administrative health and social data as a secondary use. The data were provided to the Manitoba Centre for Health Policy (MCHP) under specific data sharing agreements only for approved use at the MCHP. The original source data is not owned by the researchers or MCHP and, as such, cannot be provided to a public repository. Where necessary, source data specific to this article or project may be reviewed at the MCHP with the consent of the original data providers and the required privacy and ethics review bodies.

Acknowledgements: The authors acknowledge the Manitoba government agencies and departments that provided the data for this study, including Manitoba Health, Seniors and Active Living (MHSAL) and the Winnipeg Regional Health Authority. They also wish to acknowledge the contributions of their advisory group, which included members of the First Nations Health Directors, the First Nations Health Technicians Network and several First Nations health professionals.

Disclaimer: The data presented in this manuscript were generated as part of a contract between the University of Manitoba and Manitoba Health, Seniors and Active Living (MHSAL), a department within the Government of Manitoba. The results and conclusions are those of the authors and no official endorsement by MHSAL was intended or should be inferred.

\section{Accepted: Sept. 24, 2021}

Correspondence to: Alan Katz, alan.katz@umanitoba.ca 